\title{
Glikojen depo hastalı̆ı tip III tanilı 10 Türk olgunun mutasyon analizleri: dört yeni mutasyonun tanımlanması
}

\author{
Mutational analysis of ten Turkish patients with glycogen storage disease type III: \\ identification of four novel mutations
}

\author{
Esra Manguoğlu, Vedat Uygun*, Figen Özkaya, Güven Lüleci, Reha Artan*, Sibel Berker \\ Akdeniz Üniversitesi Tıp Fakültesi, Tıbbi Biyoloji Anabilim Dall, Antalya, Türkiye \\ *Akdeniz Üniversitesi Tıp Fakültesi, Gastroenteroloji Bilim Dalı, Antalya, Türkiye
}

\section{Özet}

Amaç: Otozomal çekinik olarak kalıtılan Glikojen depo hastalığı tip III'den, AGL gen mutasyonları sorumlu olmakla birlikte, mutasyonların dağılımı toplumlara göre değişkenlik göstermektedir. Bu çalışmanın amacı, glikojen depo hastalığı tip III tanısı almış bireylerde, toplumumuza özgü AGL gen mutasyonlarının belirlenmesine ve belirlenen mutasyonlarla hastalığın kliniği arasında ilişki kurulmasına katkıda bulunmaktır.

Gereç ve Yöntem: Karaciğer biyopsisi yapılmış ve enzimatik analizlerle glikojen depo hastalığı tip III tanısı almış sekiz farklı aileden yaşları iki ile sekiz arasında (ortalama yaş $1,7+1,1$ ) olan, toplam 10 hasta bu çalışmaya dahil edilmiştir. Bu hastaların periferik kan örneklerinden DNA'ları elde edilmiş ve AGL geninin 6, 7, 9-18, 22, 24, 29-34 numaralı ekzonları DNA dizi analizi ile incelenmiştir.

Bulgular: Çalışmamızda, iki yeni yanlış anlamlı mutasyon p.G167V ve p.Y173F, iki yeni intronik bölgede tek baz değişimi c.1284 -1G>A ve c.2002 -2A >T ile, daha önceden bilinen tek baz değişimi p.W1327X saptanmıştır. Ek olarak, çok sayıda intronik bölge varyantları bulunmuştur. Bunların dışında bazı tek nükleotid değişimleri de belirlenmiştir. On hastanın analizi sonucunda rs3736296, rs2291637, rs2035961, rs2274570, rs6692695 değişimleri sadece birer kez gözlenirken, 10 hastanın altısında IVS12-197T>G değişimi, 10 hastanın ikisinde ise rs296885 değişimi saptanmıştır.

Çıkarımlar: Genel olarak, toplam 35 kodlayıcı ekzondan oluşan AGL geninin literatüre gore 3, 4, 7, 16, 21, 25, 30 ve 31 numaralı ekzonlarında sıklıkla mutasyonlar bildirilmiş olup, bu çalışmanın sonuçları ve toplumumuzla ilgili diğer çalışmalar birlikte değerlendirildiğinde, Türk olgularda şimdiye kadar tanımlanan mutasyonların büyük bölümünün AGL geninin 31 numaralı ekzonunda bulunduğu gözlenmiştir. Bunun yanı sıra, Türk hastalarda $A G L$ gen mutasyonlarının dağılımı toplumumuzdaki genetik heterojeniteyi yansıtmaktadır. (Türk Ped Arş 2012; 47: 278-82)

Anahtar sözcükler: $A G L$ geni, glikojen depo hastalığı tip III, mutasyon

\section{Summary}

Aim: AGL gene mutations are responsible for glycogen storage disease type III which is an autosomal recessive disorder. The distribution of these mutations shows a great variance in different populations. The aim of this study is to uncover the AGL gene mutation profile among Turkish patients and to contribute to the establishment of a link between these mutations and the clinical picture of the disease.

Material and Method: A total of ten patients aged between two and eight years (mean age 1.7+1.1) who were diagnosed with glycogen storage disease type III by liver biopsy and enzymatic analysis from eight different families were included in this study. DNA was isolated from the peripheral blood samples of these patients and exons 6, 7, 9-18, 22, 24, 29-34 of the AGL gene were studied by DNA sequencing analysis.

Results: Our study revealed two novel missense mutations p.G167V and p.Y173F, two novel intronic single base substitutions c.1284-1G>A and c.2002-2A $>$ T and a known single base substitution p.W1327X. Numerous intronic variants were also identified. As a result of the analysis of ten patients, SNP's rs3736296, IVS12-197T>G, rs2291637, rs2035961, rs2274570, rs6692695, rs296885 were found in 1, 6, 1, 1, 1, 1, and 2 of the 10 patients, respectively.

Conclusions: According to the recent literature about the AGL gene which is constituted of a total of 35 coding exons, mutations have been reported frequently in exons $3,4,7,16,21,25,30$ and 31 . This study and previous studies reveal that the majority of the mutations identified in Turkish patients so far have been detected in exon 31 of the AGL gene. In addition, the distribution of $A G L$ gene mutations in Turkish patients reflects the genetic heterogeneity in our population. (Turk Arch Ped 2012; 47: 278-82)

Key words: $A G L$ gene, glycogen storage disease type III, mutation

Yazışma Adresi/Address for Correspondence: Dr. Reha Artan, Akdeniz Üniversitesi Tıp Fakültesi, Gastroenteroloji Bilim Dall, Antalya, Türkiye

E-posta: artan@akdeniz.edu.tr Geliş Tarihi/Received: 27.12.2011 Kabul Tarihi/Accepted: 08.08.20012

Türk Pediatri Arşivi Dergisi, Galenos Yayınevi tarafından basılmıştır. / Turkish Archives of Pediatrics, published by Galenos Publishing 


\section{Giriş}

Glikojen dal kırıcı enzim geni (Glycogen debranching enzyme gene, Gen sembolü: AGL), glikojen yıkımında çoklu ișlevsel bir enzim olan 1,4-alfa-D-glukan:1,4-alfa-D-glukan 4alfa-D-glükoziltransferazı ve amilo-1,6-glükozidazı kodlar (1). $\mathrm{Bu}$ gende meydana gelen mutasyonlar glikojen depo hastalığı tip III (GDH III, MIM \# 232400) ile ilişkilendirilmektedir. Glikojen depo hastalığı tip III hastalarının yaklaşık \%85'ini oluşturan ve hem karaciğer hem de kas tutulumu gösteren grup GDH IIla olarak adlandırılırken, sadece karaciğer tutulumu gösteren hastalar GDH IIlb grubunu oluşturmaktadır. Sadece glikosidaz enzim aktivitesinin kaybını gösteren hastalar GDH Illc ve yalnızca transferaz enzim aktivitesinden yoksun hasta grubu ise GDH IIld olarak sınıflandırılmaktadır (2).

Illk kez Japon bir GDH Illb hastasında AGL genindeki IVS32-12A>G mutasyonu tanımlanmış, daha sonra yapılan çeşitli çalışmalarda çok farklı tipte mutasyonların varlığı da gösterilmiştir (2-9). Mutasyonların büyük çoğunluğu sadece bir kez bildirilmiş olmasına rağmen, AGL geninde en az dört farklı tekrarlayan mutasyon bulunmuştur (5,10-13). Buna ek olarak, bazı mutasyonların dağııımının coğrafi farklılık gösterdiği belirlenmiştir (14). Yakın zamanda yapılan literatür derlemesi ile ise AGL geninde 112 farklı mutasyon bildirilmiştir (15).

Bu çalışmada, GDH III tanısı almış 10 Türk hastada AGL genindeki değişimlerin belirlenmesi ve bu olguların klinik ve biyokimyasal bulgularıyla birlikte değerlendirilerek genotipfenotip ilişkisinin kurulması amaçlanmıştır.

\section{Gereç ve Yöntem}

\section{Hastalar}

Akdeniz Üniversitesi Tıp Fakültesi Çocuk Gastroenteroloji, Hepatoloji ve Beslenme Bilim Dalı́nda izlenen olgularda, karaciğer iğne biyopsisi ile histopatolojik inceleme sonucunda glikojen depo hastalığı tanısı konulmuştur. Bu hastalardan Hollanda-Erasmus Üniversitesi-Rotterdam Klinik Genetik Laboratuvarı́nda enzimatik analizler yapılıp GDH III tanısı konmuş olan 10 hasta araştırmaya alınmıştır. Bütün hastalardan imzalı bilgilendirilmiş onam formu alınmıştır. Hastaların yaşları 2-8 yıl arasında (ortalama yaş $1,7 \pm 1,1$ ) olup kız/erkek oranı 6/4 olarak belirlenmiştir. Hastaların illk üçü kardeş olup, başvuruda hastaların \%40' ı hipoglisemi, \%33'ü karında şişlik ve \%20'si karaciğer büyüklüğü nedeniyle gönderilmiştir (Tablo 1). Hastaların \%80'inde hipoglisemi bulunmuştur ve bunların \%75'inde diyet (gece boyu sürekli gastrik yüksek karbonhidratlı beslenme, gündüz sık beslenme ve pişmemiş mısır nişastası ile destek) ile giderek iyileşme gerçekleşmiştir. Olguların \%50'sinde kas zayıflığı gözlenmiştir. $\mathrm{Bu}$ olgularda poliklinik hastaları ile karşılaştıııldığında otit sıklığında artış saptanmamıştır.

Kreatin kinaz (CK) değerleri başvuruda sadece üç hastada belirlenmiş ancak daha sonra tüm hastalarda ölçüm yapılmıştır.
Ekokardiyografi yedi olguya yapılmış, sadece 8 numaralı hastada kardiyomiyopati saptanmıştır, diğer hastalar ekokardiyografide normal bulunmuştur.

Hastaların lipit, ürik asit, eritrosit çökme hızı, total protein ve albümin değerlerinde anlamlı bir değişim saptanmamıştır.

\section{Moleküler analizler}

Hastaların periferik kan örneğinden, değiştirimiş tuzla çöktürme yöntemi kullanılarak DNA elde edilmiştir (16). Amiloalfa-1,6 glükozidaz, 4-alfa-glükanotransferaz (AGL) geninin belli bölgeleri mutasyonlar açısından taranmıştır. Altı,7,918,22,24,29-34 numaralı ekzonlar (ekzon numaralandırması kaynakça (1)'e göre yapıldı) ve ilgili ekzon-intron bağlantı bölgeleri daha önce yapılan bir çalışmadaki birincil dizilimleri kullanılarak PCR'da çoğaltılmıştır (6). Polimeraz zincir reaksiyon ürünleri \%2'lik agaroz jelde yürütülmüş ve Genius Syngene Bio görüntüleme cihazı ile UV'de görüntülenmiştir. Polimeraz zincir reaksiyon ürünlerinin saflaştırımasında 'High Pure PCR Product Purification Kit'i (Roche marka Katalog no: 11732676 001) kullanılmıştır. Dizi analizi reaksiyonu floresan tabanlı boya sonlandırıcısı sistemi (Big Dye ver.1,1, Applied Biosystems [ABI], Foster City, CA) kullanılarak gerçekleştirilmiştir. Dizi analizi örneklerine üretici firmanın talimatlarına uygun olarak $A B I$ Prism 310 (PE biosystems, Foster City, CA) cihazında kapiler elektroforezi uygulanmıştır. Sonuçlar NCBI (U.S. National Center for Biotechnology Information) nükleotid veritabanındaki AGL gen dizisi (NG_12865,1, NM_000028,2, NP_000019,2) kaynak alınarak değerlendirilmiştir. Mutasyon tanımlamalarında İnsan Genom Varyasyonu Topluluğu (Human Genome Variation Society, HGVS) isimlendirme sistemleri kullanılmıştır.

\section{Bulgular}

Hipoglisemi ya da glikojen depolanmasının uzun dönem komplikasyonları olarak boy kısalığı 10 hastanın altısında $(1,2,3,5,8$ ve 9 numaralı hastalarda), egzersiz entoleransı ve kas zayıfı̆̆ı 10 hastanın beşinde ve kardiyomiyopati 10 hastanın birinde (8 numaralı hasta) gözlemlenmiştir.

Hepatositlerde glikojen (diyastaz ile kaybolan "periodic acid-Schiff" boyası ile pozitif) birikimi ile ileri derecede genişleme saptanmıştır. Karaciğer yağlanması, periportal bağ dokusu artışı veya siroz hiçbir olguda görünmemiştir.

Kreatin kinaz düzeyleri dört hastanın üçünde ilk başvuruda artmış bulunmuştur ve daha sonra 10 hastadan dokuzunda artmış CK düzeyleri saptanmışır. Illk başvurudaki CK değerlerinin tümü mevcut olmadığı için, artmış CK değerleri daha sonra belirlenmiştir. Ancak, 10 yaşın üzerindeki altı çocuk arasında sadece bir çocukta CK düzeyi normal olup diğerlerinin hepsinde CK düzeyi yüksek bulunmuştur (ortalama $510 \pm 305 \mathrm{U} / \mathrm{L}$ ). On yaşından küçük dört çocuktan üçünde son CK değerleri normalin üstünde belirlenmişsir. Karaciğer işlev testleri 17 yaşındaki (1 numaralı) ve 18 yaşındaki (6 numaralı) hastalarda normal ve sırasıyla $71 / 94$ ve $41 / 58$ olarak bulunmuştur. İlginç olarak, 1 numaralı hastanın tersine 6 numaralı hastada yüksek CK 


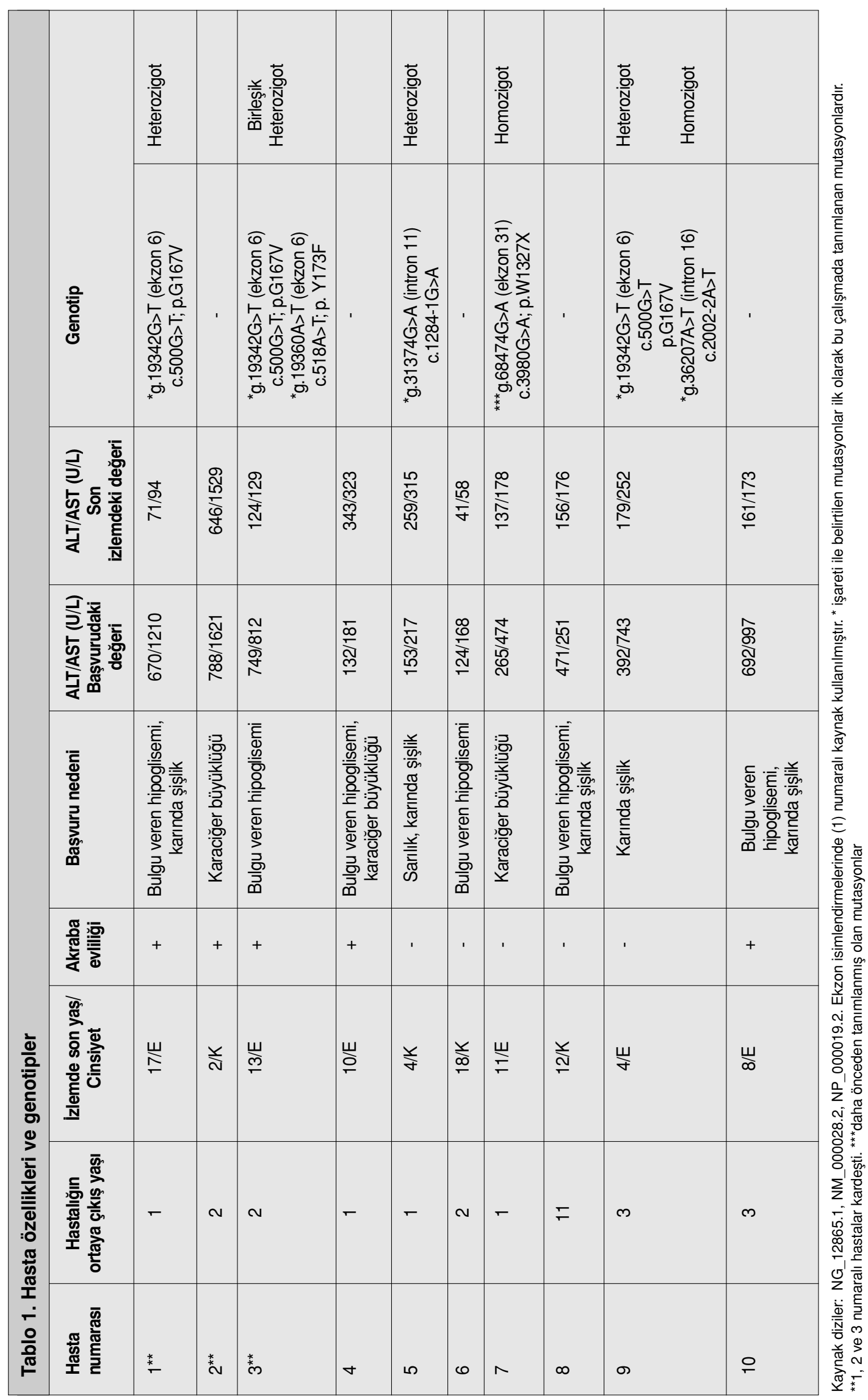


düzeyi (810 U/L) ve miyopati saptanmıştır. Transaminazlar başvuruda bütün hastalarda normal düzeyden 3-20 kat fazla olarak oldukça artmış olup, ancak 17 ve 18 yaşlarında olan 1 ve 6 numaralı hastalarda son izlemde normal bulunmuştur.

Moleküler analiz sonucunda saptanan bütün yanlış anlamlı, anlamsız ve RNA işlenimini etkileyebilecek olası intronik bölge mutasyonları Tablo 1'de sunulmuştur. İlk defa bu çalışmada tanımlanan bir yanlış anlamlı mutasyon olan p.G167V mutasyonu iki kardeşte ve bir başka hastada heterozigot olarak bulunmuştur (1, 3 ve 9 numaralı hastalar). Bir başka yanlış anlamlı yeni mutasyon olan p.Y173F mutasyonu ise kardeş hastalardan birinde ( 3 numaralı hastada) heterozigot durumda tanımlanmıştır. RNA işlenimini etkileyebilecek olan iki farklı intronik bölge değişiminden biri 5 numaralı hastada heterozigot durumda c.1284 -1 G>A; diğeri ise 9 numaralı olguda homozigot durumda c.2002 -2 A>T olarak belirlenmiştir. Bu iki değişim de ilk olarak bu çalışmada tanımlanmıştır. Daha önce başka çalışmalarda tanımlanmış olan ve "dur" kodonu oluşumuna sebep olan p.W1327X mutasyonu homozigot olarak 7 numaralı hastada saptanmıştır.

Ayrica, sessiz bir mutasyon olan c.471C>T (p.H1372H) 8 ve 10 numaralı hastalarda homozigot durumda bulunmuştur. Buna ek olarak çok sayıda intronik bölge varyantı da saptanmıştır. Çalışılan 10 hastanın altısında c.1424 -197 T>G (g.32362 T>G, IVS12-197 T>G) değişimi gözlenirken, c.2001 +8 T>C (g.36092 T>C, rs3736296, IVS16+8 T>C), c.1424 -125 T>A (g.23434 T>A, rs2291637, IVS12-125 T>A), c.2950 -21 T>A (g.46502 T>A, rs2035961, IVS23-21 T>A), c.3836 +45G>A (g.65809 G>A, rs2274570, IVS29+45G>A), c.3949 +294 A>T (g.67728 A>T, rs6692695, IVS30+294A>T) ve c.4260 -97 G>A (g.71230 G>A, rs2296885, IVS32-97G>A) değişimleri sadece birer hastada saptanmıştır.

\section{Tartışma}

Bu çalışmada, GDH III tanısı almış 10 Türk hastanın AGL gen mutasyon sonuçları, klinik ve biyokimyasal bulgularla birlikte değerlendirilmiştir. Önceki çalışmalarda olduğu gibi kas tutulumu ile CK düzeyleri arasında bir bağıntı saptanmamış olup $(17,18)$, CK düzeylerinin belirlenmesinin izlemde yinelenmesi gerektiği düşünülmektedir.

AGL geninin kısmi olarak taranması sonucunda, ilk olarak bu çalışmada saptanan p.G167Y mutasyonu 1, 3 ve 9 numaralı hastalarda gözlenmiştir. Bir ve 3 numaralı hastalar kardeş olup 9 numaralı hasta başka bir ailedendir. İlk olarak çalışmamızda tanımlanan bu mutasyonun protein düzeyinde bir aminoasit değişimine yol açtığı tahmin edilmektedir. Ancak, p.G167Y mutasyonunun GDH III tanılı üç kardeşten sadece ikisinde görülmesi ve 9 numaralı hastada p.G167Y mutasyonuna ek olarak, aynı zamanda c.2002 -2 A>T değişiminin homozigot olarak bulunmuş olması, bu mutasyonun hastalıkla ilişkilendirilemeyeceğini göstermektedir. Diğer taraftan, c.2002 2 A > T değişiminin RNA işlenimi bölgesinden sadece iki baz kadar uzakta oluşu, bu değişimin RNA işlenimini olumsuz etkileyerek anormal protein oluşumuna sebep olabileceğini ve bu genotipin fenotiple ilişkilendirilebileceğini göstermektedir. Beş numaralı hastada heterozigot olarak saptanan c.1284 -1 G>A değişimi ise yine ilk olarak bu çalışmada tanımlanan bir değişim olup, bu mutasyonun da RNA işlenimini değiştirerek protein yapısını etkileyebileceğini tahmin etmekteyiz. Ancak, bu hastadaki diğer mutant alelin araştırılmasına gereksinim vardır.

Bilinen bir anlamsız mutasyon olan p.W1327X, bir yaşında karaciğer büyüklüğü nedeni ile başvuran 7 numaralı hastada homozigot durumda bulunmuştur. Bu mutasyon daha önce Akdeniz bölgesi kökenli bir ailede (7), Mısır'lı bir ailede (19), Kanada'dan beyaz ırktan bir ailede (13), Alman-Ukraynalı bir ailede (20) ve Türkiye'nin Karadeniz bölgesinden beş ailede (12) bildirilmiştir. Bu bulgular p.W1327X mutasyonunun farklı toplumlarda gözlenen bir mutasyon olduğunu ve 7 numaralı olgunun anne ve babası arasında akrabalık olmadığı da göz önüne alındığında Türk toplumu için baskın mutasyonlardan biri olabileceğini göstermektedir.

Türk GDH III hastalarında önceki çalışmalarda en az 11 farklı mutasyon bildirilmiştir. İki Türk ailede ise IVS7 +5 G>A ve IVS21+5ins A mutasyonları saptanmıştır (13). Son zamanlarda yapılan bir çalışma sonucunda p.R1147G, p.W373X, p.R595X, p.Q1205X, p.Q667X, p.Q1376X, c.293+2T>C, p.W1327X ve c.1019delA olmak üzere dokuz farklı mutasyon belirlenmiştir (12). Bir başka yeni mutasyon olan c.2474delC de bir Türk GDH III hastasında bildirilmiştir (21). Günümüze kadar yapılan çalışmalarda AGL geninde en az dört mutasyon sık gözlenen mutasyonlar olarak öne çıkmaktadır, bunlar, IVS32-12 A>G, p.R408X, p.W1327X ve c.750-753delAGAC mutasyonlarıdır (5, 10-13). Bu mutasyonlardan Türk GDH III hastalarında bulunan sadece p.W1327X mutasyonu olup, bu mutasyon çalışmamızda da 10 olgudan birinde homozigot durumda gözlenmiştir. Bu hasta ile birlikte üç olgumuzda saptanan mutasyonların GDH IIl'ün klinik bulguları ile kesin bir bağlantısı olabileceği düşünülmektedir. Bunun yanında, kalan yedi hastada bu ilişkinin kurulabileceği genetik değişikliklerin gözlenmemesi, AGL geninde çalışmamızda taranmamış olan bölgelerdeki olası değişiklikleri dışlamamaktadır. Sonuç olarak tüm bulguların birlikte değerlendirilmesi, Türk hastalarda gözlenen klinik farklıığının, alelik farklılıkla açıklanabileceğini göstermektedir.

Bunun yanında, 2010 yılında yapılan geniş kapsamlı bir derlemede, AGL geninin 3,4,7,16,21,25,30 ve 31 'inci ekzonlarında mutasyonların en az üç ya da daha fazla hastada tanımlanmış olduğu gösterilmiştir (15). Özellikle, toplam 29 Türk GDH III hastası arasında 31 numaralı ekzonda bulunan iki mutasyondan (p.Q1376X ve p.W1327X) birinin saptandığı hasta sayısı 10'dur (12, 13, 21). Bu bulgular sonucunda, 31 numaralı ekzon şimdiye kadar Türk hastalarda saptanan mutasyonların yaklaşık 1/3'ünü içermektedir. Bu nedenle, 31. ekzonun "hot spot" bölge olabileceği ve mutasyon taramasında öncelikli bakılması gereken bölge olduğu düşüncesindeyiz.

Mutasyon tarama çalışmaları, girişimsel olmayan bir yöntem olduğundan hastalığın tanısının konmasında büyük fayda sağlamaktadır. Bazı toplumlarda olduğu gibi toplumumuzda da 
hem genetik hem de klinik farklılık gösteren GDH III hastalığında, AGL geninin daha fazla ekzonik bölgesinin ve daha fazla sayıda hastanın taranması ile genotip/fenotip ilişkisinin daha iyi kurulabileceği görüşündeyiz.

\section{Teșekkür}

Bu proje Akdeniz Üniversitesi Bilimsel Araştırma Projeleri Yönetim Birimi tarafından desteklenmiştir. Proje numarası: 2004.04.0103.022.

\section{Çıkar çatışması: Bildirilmemiştir.}

\section{Kaynaklar}

1. Bao Y, Dawson TL Jr, Chen YT. Human glycogen debranching enzyme gene (AGL): complete structural organization and characterization of the 5 ' flanking region. Genomics 1996; 38(2): 155-65.

2. Kishnani PS, Austin SL, Arn P, et al. Glycogen storage disease type III diagnosis and management guidelines. Genet Med 2010; 12(7): 446-63.

3. Okubo M, Horinishi A, Nakamura N, et al. A novel point mutation in an acceptor splice site of intron 32 (IVS32 A-12-->G) but no exon 3 mutations in the glycogen debranching enzyme gene in a homozygous patient with glycogen storage disease type Illb. Hum Genet 1998; 102(1): 1-5.

4. Shaiu WL, Kishnani PS, Shen J, Liu HM, Chen YT. Genotype-phenotype correlation in two frequent mutations and mutation update in type III glycogen storage disease. Mol Genet Metab 2000; 69(1): 16-23.

5. Horinishi A, Okubo M, Tang NL, et al. Mutational and haplotype analysis of AGL in patients with glycogen storage disease type III. J Hum Genet 2002; 47(2): 55-9.

6. Okubo M, Horinishi A, Takeuchi M, et al. Heterogeneous mutations in the glycogen-debranching enzyme gene are responsible for glycogen storage disease type Illa in Japan. Hum Genet 2000; 106(1): 108-15.

7. Lucchiari S, Fogh I, Prelle A, et al. Clinical and genetic variability of glycogen storage disease type Illa: seven novel AGL gene mutations in the Mediterranean area. Am J Med Genet 2002; 109(3): 183-90.

8. Lucchiari S, Santoro D, Pagliarani S, Comi GP. Clinical, biochemical and genetic features of glycogen debranching enzyme deficiency. Acta Myol 2007; 26(1): 72-4.
9. Endo $\mathrm{Y}$, Fateen $\mathrm{E}$, El Shabrawy $\mathrm{M}$, et al. Egyptian glycogen storage disease type III - identification of six novel AGL mutations, including a large $1.5 \mathrm{~kb}$ deletion and a missense mutation p.L620P with subtype Illd. Clin Chem Lab Med 2009; 47(10): 1233-8.

10. Okubo M, Spengos K, Manta P, Fateen E. Phenotypical variability in glycogen storage disease type III with a recurrent AGL mutation c.750753delAGAC. Muscle Nerve 2011; 43(3): 451.

11. Lam CW, Lee AT, Lam YY, et al. DNA-based subtyping of glycogen storage disease type III: mutation and haplotype analysis of the AGL gene in Chinese. Mol Genet Metab 2004; 83(3): 271-5.

12. Aoyama Y, Ozer I, Demirkol M, et al. Molecular features of 23 patients with glycogen storage disease type III in Turkey: a novel mutation p.R1147G associated with isolated glucosidase deficiency, along with 9 AGL mutations. J Hum Genet 2009; 54(11): 681-6.

13. Endo $Y$, Horinishi $A$, Vorgerd $M$, et al. Molecular analysis of the AGL gene: heterogeneity of mutations in patients with glycogen storage disease type III from Germany, Canada, Afghanistan, Iran, and Turkey. J Hum Genet 2006; 51(11): 958-63.

14. Parvari R, Moses S, Shen J, Hershkovitz E, Lerner A, Chen YT. A single-base deletion in the $3{ }^{\prime}$-coding region of glycogen-debranching enzyme is prevalent in glycogen storage disease type IIIA in a population of North African Jewish patients. Eur J Hum Genet 1997; 5(5): 266-70.

15. Goldstein JL, Austin SL, Boyette K, et al. Molecular analysis of the AGL gene: identification of 25 novel mutations and evidence of genetic heterogeneity in patients with Glycogen Storage Disease Type III. Genet Med 2010; 12(7): 424-30.

16. Miller SA, Dykes DD, Polesky HF. A simple salting out procedure for extracting DNA from human nucleated cells. Nucleic Acids Res 1988; 16: 215.

17. Kiechl S, Kohlendorfer U, Thaler C, et al. Different clinical aspects of debrancher deficiency myopathy. J Neurol Neurosurg Psychiatry 1999; 67: 364-8.

18. Coleman RA, Winter HS, Wolf B, Gilchrist JM, Chen YT. Glycogen storage disease type III (glycogen debranching enzyme deficiency): correlation of biochemical defects with myopathy and cardiomyopathy. Ann Intern Med 1992; 116: 896-900.

19. Endo $Y$, Fateen E, Aoyama $Y$, et al. Molecular characterization of Egyptian patients with glycogen storage disease type Illa. J Hum Genet 2005; 50(10): 538-42.

20. Schoser B, Gläser D, Müller-Höcker J. Clinicopathological analysis of the homozygous p.W1327X AGL mutation in glycogen storage disease type 3. Am J Med Genet A 2008; 146A(22): 2911-5.

21. Aoyama $Y$, Endo $Y$, Ebara T, et al. Novel AGL mutation in a Turkish patient with glycogen storage disease type Illa. Pediatr Int 2010; 52(1): 145-7. 